\title{
Clinical Assessment Of Bonding Agent v/s Fluoride Varnish In Dentinal Hypersensitivity
}

\author{
Jamshed Ahmed, Syed Abrar Ali, Rizwan Jouhar, Haroon Shah
}

\section{ABSTRACT:}

Objective: To compare the mean reduction in pain scores between Bonding agent (GLUMA® Comfort $\AA$ Bond + Desensitizer, and Fluoride varnish.

Methodology: The study was conducted at Operative Dentistry, Department at Altamash Institute of Dental Medicine, Karachi from July 2015 to August 2016. Total 152 patients were selected. Patients were randomly allocated into two groups A and B. Gluma comfort bond plus desensitizer ${ }^{\circledR}$ was applied to the patients in group A and Duraphet ${ }^{\circledR}$ was applied to the patients in group B. Initial assessment was done after the application of the above products and thermal test was performed. The outcomes were based on a Visual Analogue Scale (VAS). Re-Evaluation was done again after 30 days of treatment in terms of mean reduction in pain from baseline by applying thermal test on visual analogue scale.

Results: The average age of the patients was $37.4 \pm 8.38$ years. After 30 days, mean Visual Analog Scale was significantly low in Group A i.e. 2.95 \pm 0.0 .86 as compared to Group B i.e. $4.01 \pm 0.79(\mathrm{p}=0.0005)$. Significant more reduction in mean pain score was observed in Bonding agent (Gluma desensitizer) as compared to Fluoride varnish Duraphat.

Conclusion: In our study we found that bonding agent ( Gluma Desensitizer) is more effective in treating Dentine Hypersensitivity compared to fluoride varnish (Duraphat desensitizer group).

Key Words: Dentin hypersensitivity, Pain score, Bonding agent, Fluoride varnish.

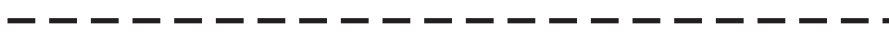

\section{INTRODUCTION:}

Dentinal hypersensitivity is becoming more and more common these days. It can be diagnosed as short and sharp pain from exposed dentine in response to tactile, evaporative, chemical or thermal stimuli ${ }^{1}$. It is associated with condition like abrasion, attrition, erosion, abfraction, gingival recession and improper brushing habits ${ }^{2,3}$. Most common teeth are canines followed by first premolars, incisors, second premolars, and molars ${ }^{4,5}$. To explain dentinal hypersensitivity many theories has been proposed ${ }^{3,4,8}$. Most authentic theory is hydrodynamic theory of sensitivity. This theory proposed that fluid move rapidly within the dentinal tubules following stimulus application resulting in stimulation of sensory nerves in the pulp/inner dentin portion of the tooth ${ }^{3}$. According to one study, deficiency of cementum (CEJ) in $5 \%$ to $10 \%$

\begin{tabular}{|c|}
\hline $\begin{array}{l}\text { Jamshed Ahmed } \\
\text { Lecturer, Bibi Aseefa Dental College, } \\
\text { Larkana }\end{array}$ \\
\hline $\begin{array}{l}\text { Syed Abrar Ali } \\
\text { Associate Professor, Department of Operative Dentistry } \\
\text { Hamdard University Dental Hospital. }\end{array}$ \\
\hline $\begin{array}{l}\text { Rizwan Jouhar } \\
\text { Associate Professor and head Operative } \\
\text { Dentistry Altamash Institute Of Dental Medicine }\end{array}$ \\
\hline $\begin{array}{l}\text { Haroon Shah } \\
\text { Assistant Professor } \\
\text { Department of Operative dentistry } \\
\text { Hamdard University Dental Hospital, } \\
\text { Hamdard University Karachi. } \\
\text { Email: dr_shahharoon@yahoo.com }\end{array}$ \\
\hline $\begin{array}{l}\text { Received: } 14-03-18 \\
\text { Accepted: } 05-12-18\end{array}$ \\
\hline
\end{tabular}

of teeth also resulted in exposed dentin and may contribute to dentinal hypersensitivity ${ }^{6}$. Moreover gingival recession, improper tooth brushing or periodontal therapy can also contribute to dentinal hypersensitivity ${ }^{2-8}$. Dentinal hypersensitivity can also be the result of scaling and root planning. The rationale of this study is to identify which treatment modality (Bonding agents or Fluoride varnish) gives better outcome in treating Dentine Hypersensitivity.

\section{METHODOLOGY:}

The study was conducted at Operative Dentistry Department at Altamash Institute of Dental Medicine, Karachi from July 2015 to August 2016.A total of 152 patients was selected by eligibility criteria.

Patient with history of dentinal hypersensitivity having cervical erosive cavities and gingival recession were included in the stydy. Patient should have at least 20 natural permanent teeth and at least two teeth with a VAS score of $=4$ to be included in the study.

Teeth with caries, defective restorations, chipped teeth, deep periodontal pockets (probing depth $>4 \mathrm{~mm}$ ), periodontal surgery within the previous six months, and subjects with orthodontic appliances or bridge work that would interfere with evaluation were excluded. Presence of occlusal overload or occlusal adjustment, any gross oral pathology, eating disorders, chronic disease were also excluded from the study sample, Patients were divided into two equal sized, random groups by lottery method. Gluma comfort bond plus desensitizer ${ }^{\circledR}$ (HeraeusKulzer, Hanau, Germany) was applied to the patients in group A, while Duraphat ${ }^{\circledR}$ (Colgate Oral Pharmaceuticals, New York) was applied to the patients in 
group B. In group A. Each tooth which was sensitive was cleaned with a polishing paste, rinsed with water and air dried. The Gluma etch gel was applied for 20 seconds. Then it was rinsed, air dried and the tooth surface was moistened by pellets damped with distilled water. Gluma comfort bond plus desensitizer ${ }^{\circledR}$ was applied using a disposable brush applicator. Another coat was applied and then it was light cured for 15 seconds.

In Group B every target sensitive tooth was cleaned with a polishing paste, rinsed with water and air dried. Disposable brush applicator was used to apply Duraphat ${ }^{\circledR}$. A second coat was applied after 5 minutes. Patients were recalled after 30 days of the treatment and visual analogue scale was used by applying thermal test.

The data analysis was carried out using SPSS (version 19). Mean and standard deviation was calculated for age, pain score at baseline and after 30 days. Mean reduction in pain score was presented in standard deviation. Frequency and percentage was calculated by gender. T-test was applied to compare the mean reduction in pain score in both groups. Stratification with respect to age and gender was done. Post stratification t-test was applied. The $p$ value $=0.05$ was considered to be statistically significant.

\section{RESULTS:}

Mean age of the patients was 37.4 years. There were 53(34.9\%) male and 99(65.1\%) female patients (Figure1).

The mean VAS for pain was $7.26 \pm 0.57$ for group A and $7.29 \pm 0.51$ for group B at the baseline. Mean difference was not significant between groups at baseline. After 30 days, Mean VAS was significantly low in Group A as compared to Group B [ $2.95 \pm 0.0 .86$ vs. $4.01 \pm 0.79 \mathrm{p}=0.0005]$. Mean reduction in pain score level of gluma desensitizer was $4.32 \pm$ 0.94 while in duraphet group it was $3.22 \pm 1.02$. Significant more reduction in mean pain score was observed in Gluma desensitizer as compared to Duraphet as shown in table 1.

Stratification analysis was also performed and observed that mean VAS reduction was also high in group $\mathrm{A}$ as compared to group B for below and equal to 40 years of age patients and above 40 years of age patients as shown in table 2 and 3 respectively. Similarly reduction was also observed in group A for male and female cases as shown in table 4 and 5 respectively.

\section{DISCUSSION:}

Hypersensitivity of dentine is very unpleasant experience perceived by patients. It is a highly painful activity resulting in unusual habits like tongue protecting sensitive teeth, avoidance in eating from that side of the mouth and complete elimination of cold hot and drink and food. The quality o flife is greatly compromised. It's difficult for the patient to describe the condition and similarly very difficult to diagnose the exact cause and subsequent management ${ }^{3}$.

The cause of dentinal hypersensitivity may be hot and cold stimulus. Tactile sensation and evaporation can also result in increasing hypersensitivity ${ }^{9,10}$. Since 1935 -Grossmann

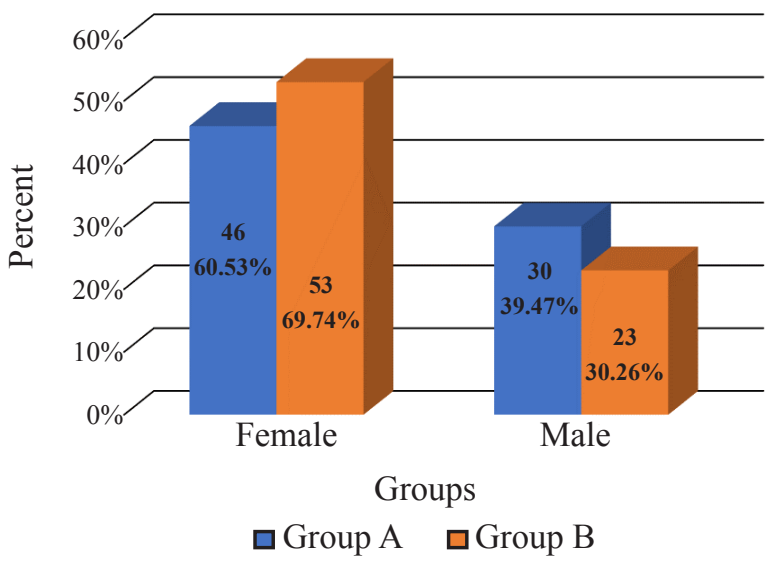

Figure 1: Gender Distribution of the Patients With Respect To Groups $(\mathrm{n}=152)$

\begin{tabular}{|l|c|c|c|}
\hline $\begin{array}{l}\text { Pain Score at } \\
\text { different time }\end{array}$ & $\begin{array}{c}\text { Group A } \\
\mathbf{n = 7 6}\end{array}$ & $\begin{array}{c}\text { Group B } \\
\mathbf{n = 7 6}\end{array}$ & P-Value \\
\hline At Baseline & $7.26 \pm 0.57$ & $7.29 \pm 0.51$ & 0.76 \\
\hline After 30 days & $2.95 \pm 0.0 .86$ & $4.01 \pm 0.79$ & 0.0005 \\
\hline $\begin{array}{l}\text { Reduction in } \\
\text { pain score }\end{array}$ & $4.32 \pm 0.94$ & $3.22 \pm 1.02$ & 0.0005 \\
\hline
\end{tabular}

Table 1: Comparison of Mean Pain Score between Groups Independent sample t test

\begin{tabular}{|l|c|c|c|}
\hline $\begin{array}{l}\text { Pain Score at } \\
\text { different time }\end{array}$ & $\begin{array}{c}\text { Group A } \\
\mathbf{n = 4 8}\end{array}$ & $\begin{array}{c}\text { Group B } \\
\mathbf{n = 5 9}\end{array}$ & P-Value \\
\hline At Baseline & $7.29 \pm 0.62$ & $7.27 \pm 0.48$ & 0.84 \\
\hline After 30 days & $2.96 \pm 0.0 .96$ & $4.02 \pm 0.0 .84$ & 0.0005 \\
\hline $\begin{array}{l}\text { Reduction in } \\
\text { pain score }\end{array}$ & $4.33 \pm 1.07$ & $3.22 \pm 1.08$ & 0.0005 \\
\hline
\end{tabular}

Table 2: Comparison of mean pain score between groups for age $=40$ years of age Independent sample $t$ test

\begin{tabular}{|l|c|c|c|}
\hline $\begin{array}{l}\text { Pain Score at } \\
\text { different time }\end{array}$ & $\begin{array}{c}\text { Group A } \\
\mathbf{n = 2 8}\end{array}$ & $\begin{array}{c}\text { Group B } \\
\mathbf{n = 1 7}\end{array}$ & P-Value \\
\hline At Baseline & $7.21 \pm 0.49$ & $7.35 \pm 0.61$ & 0.41 \\
\hline After 30 days & $2.93 \pm 0.66$ & $4.00 \pm 0.61$ & 0.0005 \\
\hline $\begin{array}{l}\text { Reduction in } \\
\text { pain score }\end{array}$ & $4.29 \pm 0.65$ & $3.24 \pm 0.83$ & 0.0005 \\
\hline
\end{tabular}

Table 3: comparison of mean pain score between groups for age above 40 years of age Independent sample t test 


\begin{tabular}{|l|c|c|c|}
\hline $\begin{array}{l}\text { Pain Score at } \\
\text { different time }\end{array}$ & $\begin{array}{c}\text { Group A } \\
\mathbf{n = 3 0}\end{array}$ & $\begin{array}{c}\text { Group B } \\
\mathbf{n = 2 3}\end{array}$ & P-Value \\
\hline At Baseline & $7.10 \pm 0.31$ & $7.13 \pm 0.34$ & 0.73 \\
\hline After 30 days & $2.97 \pm 0.99$ & $3.78 \pm 0 . .60$ & 0.001 \\
\hline $\begin{array}{l}\text { Reduction in } \\
\text { pain score }\end{array}$ & $4.13 \pm 1.07$ & $3.26 \pm 0.75$ & 0.002 \\
\hline
\end{tabular}

Table 4: comparison of mean pain score between groups for male patients

Independent sample $t$ test

\begin{tabular}{|l|c|c|c|}
\hline $\begin{array}{l}\text { Pain Score at } \\
\text { different time }\end{array}$ & $\begin{array}{c}\text { Group A } \\
\mathbf{n = 4 6}\end{array}$ & $\begin{array}{c}\text { Group B } \\
\mathbf{n = 5 3}\end{array}$ & P-Value \\
\hline At Baseline & $7.37 \pm 0.68$ & $7.36 \pm 0.56$ & 0.93 \\
\hline After 30 days & $2.93 \pm 0.77$ & $4.11 \pm 0.0 .84$ & 0.0005 \\
\hline $\begin{array}{l}\text { Reduction in } \\
\text { pain score }\end{array}$ & $4.43 \pm 0.83$ & $3.21 \pm 1.13$ & 0.0005 \\
\hline
\end{tabular}

Table 5: comparison of mean pain score between groups for female patients

Independent sample $t$ test

developed a agent to treat dentinal hypersensitivity, which is non irritant, easy to use, gives immediate result, relatively cheap with long term effect. A review by Markowitz and Pashley proposed that new desensitizing agent should treat the root causes with managing sensitivity as well ${ }^{11}$.

In this study 152 patients were divided into two groups $\mathrm{A}$ ans B. There were 53(34.9\%) male and 99(65.1\%) females. Our data shows that women are more vulnerable to hypersensitivity of dentine. A hypothesis was given that female visits the dentists more often and follow hygiene instructions more often than males ${ }^{12,13}$. In our study age of the patients ranges from 20-60 years and the average was $37.4 \pm 8.38$ years. A similar study by Cummins who demonstrated that, dentine hypersensitivity can present at any age but the majority of individuals range in age between 20 and 50 years with a peak in prevalence in the age range $30-39$ years. $^{[14]}$

In our study Gluma comfort bond plus desensitizer was applied to the patients in group A and Duraphat was applied to the patients in group B. The mean VAS for pain was $7.26 \pm 0.57$ for group A and $7.29 \pm 0.51$ for group B at the baseline. Mean difference was not significant between groups at baseline. After 30 days, mean VAS was significantly low in Group A as compared to Group B [2.95 \pm 0.0 .86 vs. $4.01 \pm 0.79 p=0.0005]$. Mean reduction in pain score level of guma desensitizer was $4.32 \pm 0.94$ while in Duraphet group it was $3.22 \pm 1.02$. Significant more reduction in mean sensitivity score was noted in Gluma Desensitizer when we compared it to Duraphet. Gluma contains glutaraldehyde which occludes dentinal tubules and develops coagulation inside the dentine tubules, because of precipitation of serum albumin ${ }^{15,16}$. Studies outcomes show a mark decrease in dentine hypersensitivity ${ }^{17,18,19}$, but other studies contradict these results ${ }^{20,21}$. Aranha et al. ${ }^{22}$ in his study concluded that an instant effect was seen after application of Gluma Desensitizer and Seal \& Protect. Fluoride compound application in higher concentration can reduce dentinal hypersensitivity which might be due to deposition of calcium fluoride globules within the dentine tubules ${ }^{23}$. Ghaffar et al concluded in their research that, professionally-applied high-fluoride products, including fluoride varnish $(22,600$ ppm fluoride) have been shown to greatly reduce dentine hypersensitivity following just one application ${ }^{24}$.

\section{CONCLUSION:}

Clinician find dentinal hypersensitivity very challenging to treat effectively. Patient education regarding managing this condition is of prime importance. With newer materials better option are available to treat the patient but to identify the real cause is of utmost importance in long term success. In our study we found that group in which bonding agents were used was more effective with a mean reduction in pain score level of $4.31 \pm 0.94$ while in the group which used fluoride varnish group it was $3.22 \pm 1.02$. A good clinician should have sound knowledge of latest materials available to treat the condition of dentinal hypersensitivity.

\section{REFERENCES:}

1. Mehmood Z, Shah JA, Javed MU, Mehmood Z, Shah JA, Javed MU, et al. Efficacy of gluma desensitizer and duraphat in relieving dentinal hypersensitivity in non-carious cervical lesions. Pak Oral Dent J. 2011;31:183-6.

2. Richard D, Oquendo A. Treatment of dentin hypersensitivity. Dent Clin N Am. 2011;55:599-608.

3. Guentscha A, Seidlera K, Nietzscheb S. Biomimetic mineralization longterm observations inpatients with dentin sensitivity. Dent Mater. 2012;10:1-3.

4. Yashen S, Tsai CH, Yang LC, Chan YC. Clinical efficacy of toothpaste containing potassium citrate in treating dentin hypersensitivity. J Dent Sci. 2009;4:173-7.

5. Dababneh RH, Khouri AT, Addy M. Dentine hypersensitivity an enigma, a review of terminology, epidemiology, mechanisms, aetiology and management. Br Dent J. 1999; 187:11.

6. Al-Sabbagh M, Amanda B, Thomas MV. In office treatment of dentinal hypersensitivity. Dent Clin N Am. 2009;53:4760.

7. Al-Sabbagh M, Harrison E, Thomas MV. Patient applied treatment of dentinal Hypersensitivity. Dent Clin N Am. 2009;53:61-70.

8. Assis CA, Antoniazzi RP, Zanatta FB, Rösing CK. Efficacy of Gluma Desensitizer ${ }^{\circledR}$ on dentin hypersensitivity in periodontallytreated patients. Braz Oral Res. 2006;20:252-6.

9. Holland GR, Narhi MN, Addy M, Gangarosa L, Orchardson $\mathrm{R}$. Guidelines for the design and conduct of clinical trials on dentine hypersensitivity. J ClinPeriodontol. 1997;24:808-13. 
10. Dowell P, Addy M, Drummer P. Dentine hypersensitivity: aetiology, differential diagnosis and management. Br J Dent. 1985;158:92.

11. Markowitz K, Pashley DH. Discovering new treatments for sensitive teeth. The long path from biology to therapy. J Oral Rehabil. 2007;35:300-15.

12. Addy M. Dentine hypersensitivity: New perspectives on an old problem. Int Dent J. 2002;52(5):367-375.

13. Brännström M. Dentin sensitivity and aspiration of odontoblasts. J Am Dent Assoc. 1963;66:366-70

14. Cummins D. Dentin hypersensitivity. From diagnosis to a breakthrough therapy for everyday sensitivity relief. J Clin Dent. 2009;20(1):1-9.

15. Dijkman GE, Jongebloed WL, de Vries J, Ogaard B, Arends J. Closing of dentinal tubules by glutardialdehyde treatment. A scanning electron microscopy study. Scand J Dent Res. 1994;102(3):144-50.

16. Bergenholtz G, Jontell M, Tuttle A, Knutsson G. Inhibition of serum albumin flux across exposed dentine following conditioning with GLUMA primer, glutaraldehyde or potassium oxalates. J Dent. 1993;21(4):220-7.

17. Felton DA, Bergenholtz G, Kanoy BE. Evaluation of the desensitising effect of Gluma dentine bond on teeth prepared for complete-coverage restorations. Int J Prosthodont. 1991;4(3):292-8.
18. Kakaboura A, Rahiotis C, Thomaidis S, Doukoudakis S. Clinical effectiveness of two agents on the treatment of tooth cervical hypersensitivity. Am J Dent. 2005;18(4):291-5.

19. Ishihata H, Kanehira M, Nagai T, Finger WJ, Shimauchi H, Komatsu M. Effect of desensitising agents on dentine permeability. Am J Dent. 2009;22(3):143-6.

20. Sobral MA, Garone-Netto N, Luz MA, Santos AP. Prevention of postoperative tooth sensitivity. a preliminary clinical trial. J Oral Rehabil. 2005;32(9):661-8.

21. deAssis C, Antoniazzi RP, Zanatta FB, Rösing CK. Efficacy of GlumaDesensitiser on dentine hypersensitivity in periodontally treated patients. Braz Oral Res. 2006;20(3):2526.

22. Aranha AC, Pimenta LA, Marchi GM. Clinical evaluation of desensitizing treatments for cervical dentin hypersensitivity. Braz Oral Res. 2009;23(3):333-9.

23. Petrou I, Heu R, Stranick M, Lavender S, Zaidel L, Cummins $\mathrm{D}$, et al. A breakthrough therapy for dentine hypersensitivity. how dental products containing $8 \%$ arginine and calcium carbonate work to deliver effective relief of sensitive teeth. J Clin Dent. 2009;20(1):23-31.

24. Gaffar A. Treating hypersensitivity with fluoride varnishes. CompendContinEduc Dent. 1988;19:1088-97. 